\section{Service recovery's impact on customers next-in-line}

\section{Service recovery's impact}

\author{
Yves Van Vaerenbergh \\ Hogeschool-Universiteit Brussel, Brussels, Belgium \& Ghent University, \\ Ghent, Belgium \\ Iris Vermeir \\ University College Ghent \& Ghent University, Ghent, Belgium, and \\ Bart Larivière \\ Ghent University, Ghent, Belgium
}

495

Received 12 March 2013 Revised 10 June 2013 Accepted 9 July 2013

\begin{abstract}
Purpose - Previous research considers service recovery as a one-on-one interaction between a service provider and a complaining customer. However, customers frequently complain at the place where they receive the service, making an investigation of the impact of a service recovery on observing customers necessary. Using observational learning theory and attribution theory as theoretical anchors, this paper examines whether observing a service recovery influences the observing customers' satisfaction and repurchase intentions. In addition, this paper tests whether service quality perceptions mediate, and customers' locus of control attributions moderate these relationships.

Design/methodology/approach - Study 1 tests the main hypothesis using a scenario-based experiment in two settings (restaurant, retail). Study 2 further elaborates on these findings using a scenario-based experiment in a hotel setting.

Findings - The findings show that the negative consequences of a failed recovery extend beyond the complaining customers to observing customers, whereas the positive consequences of observing a satisfactory recovery do not influence the observing customer when compared to observing a failurefree service delivery. These relationships are driven by the service quality information customers extract from observing a service recovery. In addition, the results indicate that the negative spill-over effects are attenuated if the observing customer gets information about who caused the failure.

Originality/value - From a theoretical point of view, this study contributes by outlining service recovery's different impacts on complaining and observing customers: whereas service recovery forms a critical for complaining customers, it only acts as a dissatisfier for observing customers. In addition, it is the first to test a potential explanation for why observing a service recovery leads to lower customer outcomes, and provides insights about how service providers might attenuate the negative spill-over effects of a failed recovery.
\end{abstract}

Keywords Service failure, Service quality, Service recovery, Observational learning, Other customers Paper type Research paper

\section{Introduction}

Service failures are pervasive in service encounters and they negatively affect customer satisfaction and behavior (Svari et al., 2010). The topic of complaint handling thus receives considerable attention. Numerous studies demonstrate a satisfactory service recovery's potential to restore customer satisfaction and behavioral intentions (Orsingher et al., 2010; Priluck and Lala, 2009). However, these studies examine service recovery and its effects exclusively from the complainer - service provider perspective and do not focus on the presence of other customers. Other customers are often present in the service environment during a service encounter (Choi and Kim, 2013) and they might observe this service recovery especially since customers mostly complain at the place where they receive the service (Lovelock and Wirtz, 2011). For example, 
MSQ

23,6

496
Goodman (1999) indicates that all airline passengers experiencing a service failure complain to the flight attendant, and not to the company's headquarters or a third party. To the authors' knowledge, no research examines the impact of observing a service recovery on customer satisfaction and repurchase intentions.

This paper draws upon observational learning theory and attribution theory to addresses this void in literature. It proposes a theoretical mechanism for explaining why observing a service recovery might influence the observing customers' outcomes. More specifically, observing an unsatisfactory service recovery allows observing customers to learn about the service provider's service quality. While it seems obvious that observing a negative service recovery influences the observing customers negatively, this paper suggests that this is not always the case. It is known that observing negative events trigger attributions about who is to blame (Cowley, 2005). Given that people make attributions based on information that is received or perceived (Weiner, 2000), observing customers might attribute the cause of the failure to either the complaining customer or the service provider. These locus of control attributions may be derived from an employee's explanations (Bitner, 1990). This paper thus examines whether locus of control attributions (i.e. whether the failure was caused by the complaining customer or by the service provider) moderate the relationships between an observed service recovery and customer outcomes.

The remainder of this paper is structured as follows. First, we provide the theoretical background and the research design. Second, we provide a discussion of the results of two studies. Third, we outline some limitations and implications for further research.

\section{Theoretical background}

\section{Service recovery}

Service recovery is defined as the actions a service provider takes in response to a customer complaint (Grönroos, 1988), or as the actions designed to resolve customers' problems, alter negative attitudes of dissatisfied customers, and ultimately retain these customers (Miller et al., 2000). Service recovery thus represents a critical moment of truth for an organization, as an unsatisfactory response to a customer complaint might lead to losing the complaining customer (Michel et al., 2009). The literature devotes considerable attention to this issue, and identifies a number of possible responses to customer complaints. These responses may include solving the customer's problem and/or offering a compensation, offering an apology, displaying favorable behavior such as active listening, being courteous, showing empathy, and providing a speedy recovery (Gruber et al., 2009; Liao, 2007; Ozgen and Kurt, 2012). A satisfactory service recovery has the potential to restore customer satisfaction and repurchase intentions (Michel et al., 2009).

The service recovery literature examines service recovery exclusively from a service provider - complaining customer perspective. For example, Edvardsson et al. (2011) propose a model outlining the behavior of different actors in a complex service recovery process. Their model examines multiple service recovery encounters between a service provider (represented by employees and managers) and a complaining customer. As mentioned earlier, our study uses the observational learning and attribution theories to investigate the effects of service recovery on observing customers' satisfaction and repurchase intentions, rather than the complaining customers' outcomes. In addition, this study examines whether observing a service recovery serves as an opportunity for other customers to learn about the service 
provider's service quality, and whether the observing customers' inferences about the locus of control of the service failure attenuate these effects. Figure 1 provides an overview of the conceptual framework guiding this study. In the next sections, we provide the theoretical conceptualization of the various relationships.

\section{Service recovery's impact}

Observational learning as theoretical anchor

Observational learning theory serves as a theoretical anchor for examining the impact of an observed service recovery on customer outcomes. Bandura (1977) distinguishes between two types of observational learning: first, imitation, which is matching the topography of an observed person's behavior, and second, vicarious learning, which is the increase or decrease of an observer's attitudes and behaviors that are similar to that of the observed person, as a result of observing whether or not the observed person's attitudes and behavior lead to satisfactory or unsatisfactory outcomes (Masia and Chase, 1997). The aim of this paper is to examine customer outcomes after observing a (un)satisfactory service recovery, hence, the term observational learning refers to vicarious learning.

Bandura (1971) notes that virtually all learning resulting from direct experience can also happen through observation of other people's behaviors and the attendant affective and behavioral consequences. An observer acquires responses to a stimulus (e.g. an attitude) by observing the experiences of others, as if $\mathrm{s} / \mathrm{he}$ had the experience with the stimulus object him-/herself (Kanekar, 1976). Observational learning is efficient; learning would be exceedingly laborious if people had to rely solely on the effects of their own actions to inform them about what to do (Bandura, 1977). In other words, other persons' experiences provide the observer with additional knowledge about which behaviors lead to satisfactory or unsatisfactory outcomes, in addition to his or her own direct experiences (Bandura, 1977; Kanekar, 1976).

Recent studies investigate observational learning effects in a service context. For example, Cai et al. (2009) demonstrate that restaurant visitors learn from other consumers' food choices. If restaurant visitors receive ranking information of the five most popular dishes at their table, the demand for these dishes increases by 13 to 20 percent. Service researchers also recognize the importance of understanding observational learning effects. In a literature review on customer-to-customer interactions, Libai et al. (2010) stress that while previous research focusses mainly on the learning effects of wordof-mouth, research should also explore observational learning. These perspectives are different in the sense that learning from word-of-mouth is more indirect. Customers who learn from word-of-mouth must rely on experiences that they did not observe directly (Kuo et al., 2013; Wirtz et al., 2013). In other words, observational learning involves customers seeing another customer's experience with their own eyes.

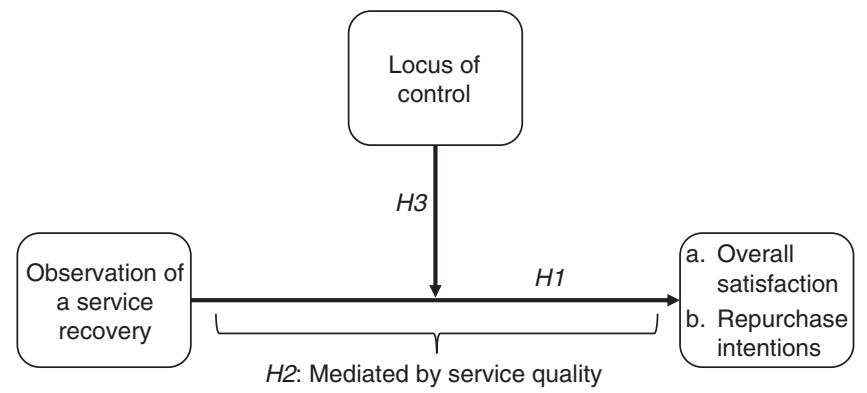

Figure 1. Conceptual framework 
MSQ

23,6

498
Observational learning effects can be quite strong, as it may even lead people to ignoring their own prior attitudes and behavioral intentions (Bikhchandani et al., 1998). However, previous research on observational learning mainly focussed on behavioral effects of observing other people (e.g. Bandura, 1977). This paper aims to provide insights into observational learning's effects on satisfaction and repurchase intentions. The main question is whether customers' overall satisfaction and repurchase intentions differ after observing an unsatisfactory or satisfactory service recovery. Previous research shows that attitudes can change rather quickly with relatively little counter attitudinal information and that it is highly context dependent (Anderson, 1971; Gawronski et al., 2010). Hence, observing a satisfactory (unsatisfactory) service encounter might affect the observer's customer outcomes (un)favorably. We therefore hypothesize that:

H1. Customers observing an unsatisfactory service recovery have lower overall satisfaction $(H 1 a)$ and repurchase intentions $(H 1 b)$ than customers observing a satisfactory service recovery.

\section{Process underlying observed service recovery effects on customer outcomes}

Zhang (2010) demonstrates that people do not only learn about attitudes and behaviors by observing others, they also learn about product quality, especially when the observed behavior conveys relevant quality information. Customers may learn about service quality by observing how a service provider responds to another customer's complaint. After all, service recovery is the critical moment of truth for an organization (Michel et al., 2009). As such, observing a service recovery is an interesting opportunity for customers to learn about an organization.

Observational learning theory predicts that negative information decreases quality perceptions (Zhang, 2010). If an observing customer notices that another customer receives an unsatisfactory service recovery, the observing customer may infer that the service quality of this provider falls below standards. On the other hand, if a customer observes that another customer receives a satisfactory service recovery, the observing customer may infer that the service quality is good or restored to the expected level. Ultimately, service quality perceptions influence customer satisfaction and repurchase intentions (Cronin et al., 2000; Larivière, 2008). We hypothesize:

H2. Perceived service quality mediates the relationship between an observed service recovery and the observer's overall satisfaction $(H 2 a)$ and repurchase intentions $(H 2 b)$.

\section{The moderating role of locus of control attributions}

Whether observing a service recovery has a strong impact on customer outcomes or not is expected to vary as a function of the locus of control over the service failure. Locus of control attributions refer to whether a service failure is caused by a service provider or a customer (Weiner, 2000). Locus of control attributions are also relevant in a context where one observes two other people. In this case, locus of control attributions refer to whether the service failure is caused by the service provider or the other customer (Cowley, 2005).

Regardless of whether the company or the customer caused the failure, observing customers should have high levels of customer outcomes if the service provider provides a satisfactory service recovery to the complaining customer. This is because a 
satisfactory service recovery signals high levels of service quality (De Ruyter et al., 1998). The observing customers will therefore have high levels of overall satisfaction and repurchase intentions.

Weiner (2000) suggests that locus of control attributions mainly attenuate customer reactions to negative events. We therefore predict that the attributions mainly attenuate the effects of observing an unsatisfactory service recovery. If the service provider is responsible for the service failure, the observing customers learn that the service quality is not always reliable (Michel et al., 2009). Customers generally expect a service provider to provide a satisfactory response to a complaint (Bitner, 1990) and this signals responsiveness from the service provider (Grewal et al., 2008). Failure to do so illustrates flaws in the service quality and the accumulated negative service quality perceptions are likely to impact negatively on the observer's satisfaction and repurchase intentions.

A service provider may also explain to the observing customer that the complaining customer caused the service failure. In this situation, the failure falls outside the service provider's control (Weiner, 2000); the observing customer may thus maintain positive service quality perceptions. Furthermore, customers generally perceive complaining customers in a negative way (Goodwin and Spiggle, 1989), especially in situations where they caused the negative event themselves (Kowalski, 2003). After all, the customer complains, but there is little that the service provider could have done about it. The observing customer might then empathize with the employee who had to deal with the complaining customer and may even find it more acceptable if the service provider provides an unsatisfactory response to the customer's complaint. We summarize this as a hypothesis:

H3. The impact of an unsatisfactory observed service recovery on overall satisfaction $(H 3 a)$ and repurchase intentions $(H 3 b)$ is less strong if the failure is caused by the complaining customer than if the failure is caused by the service provider.

\section{Overview of studies}

This paper presents two experimental studies, designed to examine the impact of a service recovery on an observing customers' overall satisfaction and repurchase intentions. Study 1 examines the impact of an observed recovery on customer outcomes in two different settings: a french-fries take-away restaurant, and a retail setting. Study 2 examines service quality perceptions as mediators in the relationship between an observed recovery and customer outcomes in a hotel setting, and tests the moderating role of locus of control on the relationships between an observed service recovery and customer outcomes.

Study 1

Method. Study 1 employs a three-group, between-subjects experiment, with two groups representing different levels of service recovery (i.e. customers experiencing a failure and receiving either an unsatisfactory or a satisfactory service recovery). The third group is a control group which does not experience a failure. Similar to previous research (e.g. Lii and Lee, 2012; Lin et al., 2011), we use a scenario-based experiment to test the proposed hypotheses. Scenarios are often used in service recovery research, and have the advantage of eliminating difficulties associated with observation or enactment of service recovery incidents in real life, such as the expense 
MSQ

23,6

500 or time involved, managerial undesirability of imposing service failures on customers, and ethical considerations (Bitner 1990). Scenarios also have the advantage of reducing biases from memory retrieval when using recall-based designs (Smith et al., 1999).

The study contexts involve a restaurant and a food retailer, and rely on a student and an adult sample, respectively. Testing the hypothesis in two settings enhances the generalizability of the results. In addition, Peterson (2001) recommends comparing results from student and adult populations in order to strengthen confidence in the generalizability of results from a student to an adult population. Therefore, we examine the effects of observing a service recovery in both a student and an adult population. In the restaurant setting, ninety undergraduate students (54.4 percent male, $M_{\text {age }}=21.3$, $\left.\mathrm{SD}_{\text {age }}=1.7\right)$ observe another customer in a french-fries take-away restaurant setting. The data from the students were collected in class, before the start of a lecture. In the retail setting, 76 adults (46.7 percent male, $M_{\text {age }}=39.0, \mathrm{SD}_{\text {age }}=13.3$ ) observe another customer in a food retail store. Adult respondents were recruited in a quiet place in a train station, while they were waiting for their train. Hair et al. (2006) recommend that every experimental condition have at least 20 observations. The sample sizes in both settings fulfill this criterion.

Manipulations. All respondents were asked to imagine themselves as the observing customer in a scenario. The scenarios described the respondents as queuing in either a french-fries take-away restaurant or at a food retail store. There is only one customer in front and this customer is complaining to the service provider. The respondent overhears this conversation. In the restaurant setting, the complaining customer was at the french-fries take-way restaurant earlier. When she/he arrived at home, she/he noticed that the order was incomplete. One portion of french-fries was missing, and the customer received a burger instead of chicken dips. In the food retail setting, the complaining customer has also been at the food retail store earlier in the day. While unpacking the groceries at home, she/he noticed that one of the products had past the expiration date. This customer returned to the store, and asks for a replacement. The complaining customer asks to get the problem solved.

Respondents then read a description of either an unsatisfactory or a satisfactory service recovery. Previous service recovery studies provided input for the service recovery manipulations (e.g. Liao, 2007; Van Vaerenbergh et al., 2012). In the satisfactory service recovery scenarios, the complaining customer receives an apology and the service provider shows empathy. The service provider also provides an explanation for the service failure (restaurant: crowded environment, food retail: something must have gone wrong), solves the complaining customers problem (replacement of the order in both settings) and offers a compensation (restaurant: free can of soda, food retail: extra points added to the customer's loyalty card). In the unsatisfactory service recovery, the service provider neither apologizes nor provides an explanation or compensation. The service provider also does not show empathy, does not solve the complaining customer's problem, and does not offer a compensation. In the control group, the respondent observes a failure-free service delivery. In the restaurant setting, the service provider prepares and delivers the customer's order in front of the respondent without any mistakes. In the food retail setting, the customer in front simply pays his bill and leaves the store without experiencing a service failure. After reading one of the three scenarios, all respondents read that the service provider serves them in an appropriate manner, without any mistakes.

Measures. The respondents rated their overall satisfaction and repurchase intentions on three-item seven-point Likert scales developed by Maxham and 
Netemeyer (2002). An adapted version of Maxham and Netemeyer's (2002) three-item seven-point Likert scale assesses the manipulation of the level of service recovery. In addition, a two-item seven-point Likert scale by Liao (2007) measures scenario realism was also presented. Table I provides an overview of the different measures and their Cronbach's $\alpha$ 's. All the measures have reliabilities greater than the recommended 0.7 threshold. The respondents also provided demographic information.

Results. Manipulation checks. We first test whether the manipulations worked as intended. Independent samples $t$-tests (restaurant: $t(58)=23.76, p<0.001$; retailer: $t(48)=15.41, p<0.001)$ indicate that the respondents reading a scenario in which the complaining customer received an unsatisfactory service recovery report significantly lower satisfaction with service recovery (restaurant: $M=1.7, \mathrm{SD}=0.8$; retailer: $M=1.9, \mathrm{SD}=1.4$ ) than respondents reading the satisfactory service recovery scenario (restaurant: $M=6.1, \mathrm{SD}=0.6$; retailer: $M=6.3, \mathrm{SD}=0.6$ ). Additionally, participants

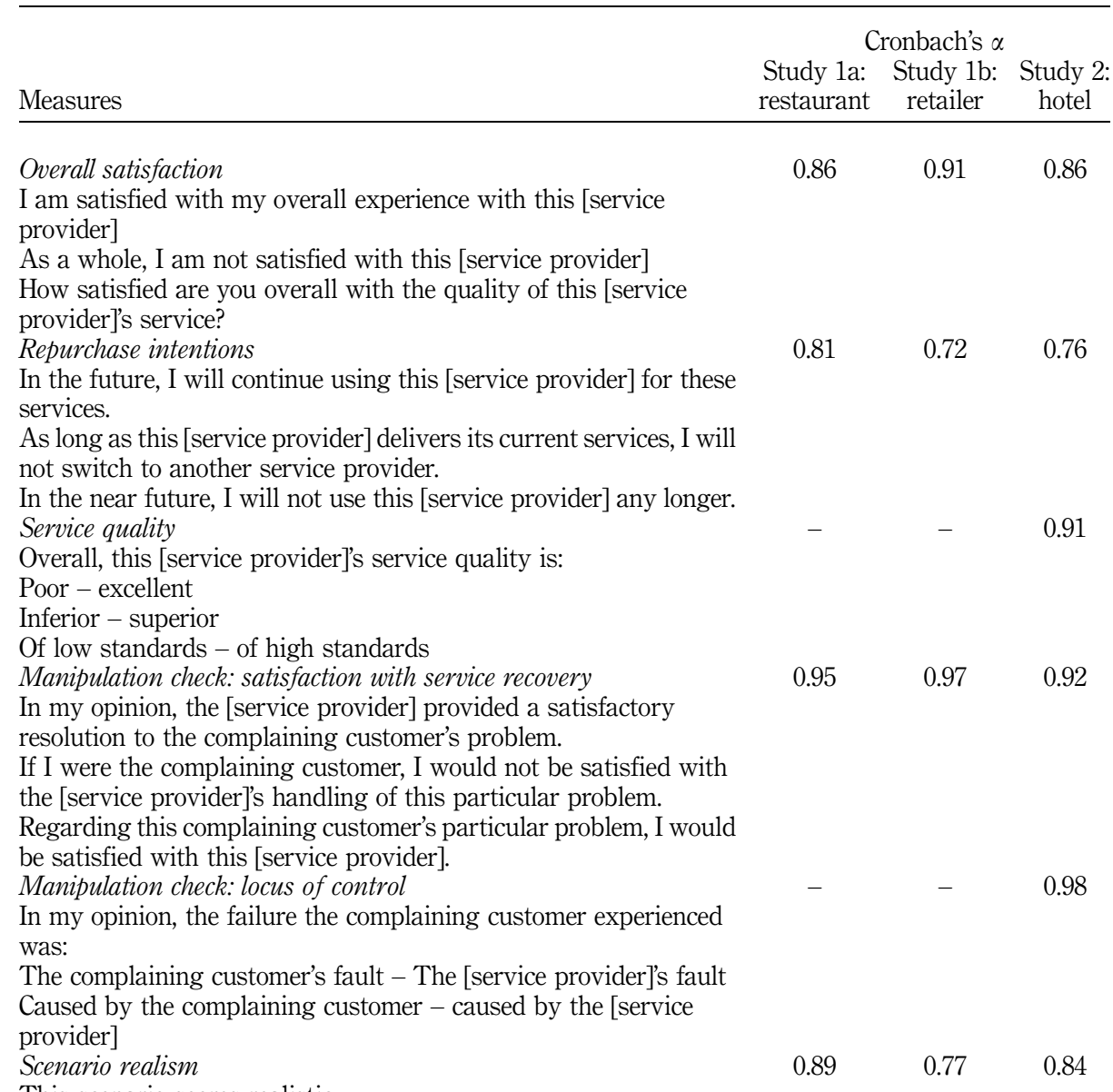

This scenario seems realistic

What happens in this scenario could also happen in real life

Table I.

Notes: All questions were measured on a seven-point Likert scale, unless indicated otherwise 
MSQ

23,6

502

Table II.

Cell means and analysis of variance results (Study 1) evaluated the scenarios as realistic in both settings (restaurant: $M=5.5, \mathrm{SD}=1.4$; retailer: $M=5.8, S D=1.1$ ). Analyses of variance (ANOVAs) tests indicate that the mean realism scores do not differ across the three conditions (restaurant: $F(2,87)=1.04$, $p>0.05$; retailer: $F(2,73)=2.69, p>0.05)$. Altogether, these findings suggest that the manipulations work as intended.

Hypothesis testing. The first hypothesis suggests that customers observing an unsatisfactory service recovery would have lower overall satisfaction $(\mathrm{Hla})$ and repurchase intentions $(H 1 b)$ than customers observing a satisfactory service recovery. These hypotheses are tested using one-way ANOVA and the results are listed in Table II. Statistically significant differences occur across the three conditions for overall satisfaction (restaurant: $F(2,87)=49.48, p<0.001$; retailer: $F(2,73)=132.17$, $p<0.001$ ) and repurchase intentions (restaurant: $F(2,87)=14.21, p<0.001$; retailer: $F(2,73)=6.13, p=0.003)$. Table II also shows the descriptive statistics. Post hoc tests using Bonferroni's method show that customers observing an unsatisfactory service recovery have significantly lower overall satisfaction (Restaurant: $M=3.8$; Retailer: $M=3.1$ ) than customers observing a satisfactory service recovery (Restaurant: $M=5.9$; Retailer: $M=6.4$, both $p$-values $<0.05)$ or a failure-free service delivery (Restaurant: $M=5.9$; Retailer: $M=6.0$, both $p$-values $<0.05$ ). In both the restaurant and the retailer setting, the results for the satisfactory service recovery and the failurefree delivery groups do not differ significantly $(p>0.05)$. These findings support $H 1 a$ in both settings. Similar findings occur for repurchase intentions. The post hoc tests indicate that customers observing an unsatisfactory service recovery have significantly lower repurchase intentions (Restaurant: $M=4.5$; Retailer: $M=5.7$ ) than customers observing a satisfactory service recovery (Restaurant: $M=5.9$; Retailer: $M=6.5$, both $p$-values $<0.05$ ) or a failure-free service delivery (Restaurant: $M=5.7$; Retailer: $M=6.2$, both $p$-values $<0.05)$. Again, the two latter groups do not significantly differ $(p>0.05)$. These findings support $H 1 b$ in both settings.

Discussion. Across two different settings, the findings of Study 1 consistently show that customers observing an unsatisfactory service recovery have lower overall satisfaction and repurchase intentions than customers observing a satisfactory service recovery or a failure-free service delivery. In addition, the two latter groups do not differ significantly. This illustrates that while service providers' unsatisfactory responses to customer complaints clearly have negative effects on observing customers, the service providers' satisfactory responses do not yield enhanced

\begin{tabular}{lcccc}
\hline & \multicolumn{2}{c}{ Study 1a: restaurant } & \multicolumn{2}{c}{ Study 1b: retail store } \\
Overall & $\begin{array}{c}\text { Repurchase } \\
\text { sntentions }\end{array}$ & $\begin{array}{c}\text { Overall } \\
\text { satisfaction }\end{array}$ & $\begin{array}{c}\text { Repurchase } \\
\text { intentions }\end{array}$ \\
\hline Unsatisfactory OSR & $3.8(1.4)^{\mathrm{a}}$ & $4.5(1.6)^{\mathrm{a}}$ & $3.1(1.0)^{\mathrm{a}}$ & $5.7(1.1)^{\mathrm{a}}$ \\
Satisfactory OSR & $5.9(0.6)^{\mathrm{b}}$ & $5.9(0.8)^{\mathrm{b}}$ & $6.4(0.6)^{\mathrm{b}}$ & $6.5(0.4)^{\mathrm{b}}$ \\
Failure-free service & $5.9(0.7)^{\mathrm{b}}$ & $5.7(0.8)^{\mathrm{b}}$ & $6.0(0.7)^{\mathrm{b}}$ & $6.2(0.7)^{\mathrm{b}}$ \\
(control) & 49.48 & 14.21 & 132.17 & 6.13 \\
$F$ & $<0.001$ & $<0.001$ & $<0.001$ & 0.003 \\
$p^{2}$ & 0.53 & 0.25 & 0.78 & 0.14
\end{tabular}

Notes: OSR, observed service recovery, standard deviations are listed between brackets, ${ }^{\mathrm{a}, \mathrm{b}}$ different letters denote significant differences in cell means using Bonferonni post hoc tests 
customer outcomes of the observing customers. These findings suggest that an unsatisfactory service recovery do not only affect the complaining customers' outcomes as substantiated by existing literature, but it also affects the outcomes of customers observing the service recovery.

Study 2 replicates these findings in a different setting and additionally examines the mediating role of service quality perceptions as a theoretical anchor, and the moderating role of locus of control.

Study 2

Method. One-hundred thirty-nine undergraduate students (42.8 percent male, $\left.M_{\text {age }}=21.25, \mathrm{SD}_{\text {age }}=3.79\right)$ participated in a 2 (observed recovery: unsatisfactory or satisfactory) $\times 2$ (Locus of control: Complaining customer caused the failure or service provider caused the failure), between-subjects experiment, conducted in a hotel setting. Participants were randomly assigned to one of the four conditions.

In the scenario, the respondent and a friend went on a holiday and arrived at a hotel. When checking in, there was only one (complaining) customer in front of them. From the conversation, it appeared that there was no room available for this customer. In the case where the locus of control was with the hotel, the check-in employee explained that the hotel made an error during the reservation. While planning the complaining customer's hotel stay, the room was erroneously booked starting the fourth of next month, instead of the fourth of the current month. In the case where the locus of control was with the complaining customer, the check-in employee explained that the customer made an error during the online reservation. While booking online, the customer booked the room erroneously starting the fourth of the next month, instead of the fourth of the current month. For the moment, the hotel has no rooms available so the customer cannot stay in the hotel. Respondents then read a description of either an unsatisfactory or a satisfactory service recovery.

The manipulations for the level of observed service recovery are similar to those used in Study 1. In the satisfactory service recovery condition, the employee apologized for the inconvenience, showed empathy, and searched for a solution. The employee contacted other hotels to see if they had a room available, which was the case. The employee indicated that the customer would be picked up within half an hour. The employee also offered a free drink in the hotel lobby. In the unsatisfactory service recovery condition, the employee did not make these efforts, and no room was made available for the customer. Finally, the scenario ends by stating that the respondent was served next. During this encounter, everything went smoothly, and the respondent did not experience any problems.

Measures. Overall satisfaction and repurchase intentions were measured using the same scales as Study 1. Afterwards, the respondents rated the perceived service quality on a three-item seven-point semantic differential scale developed by Cronin et al. (2000). The service recovery manipulation was assessed also using the same scales as in Study 1. Scenario realism is measured with the same scales as in Study 1. In addition, a two-item seven-point semantic differential scale adopted from Russell (1982) assessed the locus of control manipulation. Table I gives an overview of the different measures and their respective Cronbach's $\alpha$ 's. All measures had a reliability greater than the recommended 0.7 threshold.

Results. Manipulation checks. We first examine whether the manipulations worked as intended. An independent samples $t$-test $(t(136)=17.05, p<0.001)$ indicates that the respondents reading a scenario in which the complaining customer receives an 
MSQ

23,6

504 unsatisfactory service recovery have a significantly lower satisfaction with the observed service recovery $(M=2.0, \mathrm{SD}=1.3)$ than respondents reading the satisfactory service recovery scenario $(M=5.5, \mathrm{SD}=1.0)$. A second independent samples $t$-test $(t(136)=11.02, p<0.001)$ reveals that if the service provider explains that the complaining customer caused the failure, the respondents believe that the locus of control was with the complaining customer $(M=2.6, \mathrm{SD}=1.9)$; if the explanation reveals the hotel caused the failure, respondents perceive that the locus of control is with the hotel $(M=5.9, \mathrm{SD}=1.6)$. The respondents also evaluate the scenarios as realistic $(M=6.1$, $\mathrm{SD}=1.0)$. ANOVA indicates that the mean realism scores do not differ across the four conditions $(F(3,134)=2.32 ; p>0.05)$. Altogether, these findings suggest that the manipulations work as intended.

Hypothesis testing. ANOVAs are used to test the effects of the four scenarios on customers' overall satisfaction and repurchase intentions. The results are listed in Table III. The first hypothesis predicts that observing an unsatisfactory service recovery has a negative impact on overall satisfaction $(H 1 a)$ and repurchase intentions $(H 1 b)$. The main effects of observing a recovery are significant for overall satisfaction $(F(1,135)=33.63, p<0.001)$ and repurchase intentions $(F(1,135)=6.85, p<0.01)$. In line with the findings of Study 1, customers who observe an unsatisfactory service recovery have lower overall satisfaction $(M=5.2, \mathrm{SD}=1.1)$ and repurchase intentions $(M=5.1, \mathrm{SD}=1.2)$ than customers who observe a satisfactory service recovery (overall satisfaction: $M=6.2, \mathrm{SD}=0.7$; repurchase intentions: $M=5.6, \mathrm{SD}=0.7$ ). These findings provide additional support for $H 1 a$ and $H 1 b$.

The second hypothesis posits that the relationships of an observed service recovery with overall satisfaction $(H 2 a)$ and repurchase intentions $(H 2 b)$ would be mediated by service quality perceptions. Mediation can be tested by estimating three regression models, showing that first, the independent variable influences the dependent variable, second, the independent variable affects the mediating variable, and third, when the independent and mediating variables are included in the same regression model, there is a significant effect of the mediator on the dependent variable, and the effect of the independent variable on the dependent variable dissipates (Zhao et al., 2010). Following this logic, mediation analyses are used test whether service quality mediates the relationship between observed service recovery and the dependent variables (overall satisfaction: $b=0.91, \mathrm{SE}(b)=0.16, t(138)=5.62, \quad p<0.001$; repurchase intentions: $b=0.45, \mathrm{SE}(b)=0.17, t(138)=2.64, p<0.01)$ using a bootstrap resampling method based on 5,000 resamples (Preacher and Hayes, 2004). The results reveal significant indirect effects (overall satisfaction: $a \times b=0.60, \mathrm{SE}=0.12$; repurchase intentions: $a \times b=0.61, \mathrm{SE}=0.13$ ), with a 99 percent confidence interval excluding 0 (overall satisfaction: 0.36-0.83, repurchase intentions: 0.37-0.86). The Sobel test is also significant for both relationships (overall satisfaction: $z=4.92, p<0.001$; repurchase intentions: $z=4.86, p<0.001)$. In general, unsatisfactory service recovery decreases consumers' perceptions of service quality $(b=0.93, \mathrm{SE}(b)=0.16, \quad t(139)=5.77$, $p<0.001)$. When the effects of an observed service recovery is held constant, service quality increases overall satisfaction $(b=0.64, \mathrm{SE}(b)=0.07, t(138)=9.62, p<0.001)$ and repurchase intentions $(b=0.66, \mathrm{SE}(b)=0.07, t(138)=9.15, p<0.001)$. The direct effect of an observed service recovery on overall satisfaction also becomes less strong $(b=0.32, \operatorname{SE}(b)=0.14, t(138)=2.26, p<0.05)$, hence, this mediation is classified as complementary (Zhao et al., 2010). These findings provide partial support for H2a. In addition, the direct effect of an observed service recovery on repurchase intentions $(b=-0.16, \mathrm{SE}(b)=0.15, t(138)=-1.04, p>0.05)$ becomes insignificant, hence, 
this mediation is classified as indirect only (Zhao et al., 2010). These findings support $H 2 b$.

The third hypothesis predicts that locus of control attributions moderate the effects of observing a service recovery on overall satisfaction $(H 3 a)$ and repurchase intentions (H3b). To test these hypotheses, we examine the interaction effects in the ANOVA results in Table III. The interaction effects between observed service recovery and locus of control are significant for overall satisfaction $(F(1,135)=8.58, p<0.01)$ and repurchase intentions $(F(1,135)=4.68, p<0.05)$. The interactions, plotted in Figure 2,

\section{Service recovery's impact}

505

\begin{tabular}{|c|c|c|c|c|c|c|c|}
\hline & \multicolumn{3}{|c|}{ Overall satisfaction } & \multicolumn{3}{|c|}{ Repurchase intentions } & \\
\hline & $F$ & $p$ & $\eta^{2}$ & $F$ & $p$ & $\eta^{2}$ & \\
\hline Observed service recovery (OSR) & 33.63 & $<0.001$ & 0.20 & 6.85 & 0.009 & 0.05 & Table III. \\
\hline Locus of control (LOC) & 3.93 & 0.049 & 0.03 & 2.10 & 0.149 & 0.02 & Analysis of variance \\
\hline OSR *LOC & 8.58 & 0.004 & 0.06 & 4.68 & 0.032 & 0.03 & results (Study 2) \\
\hline
\end{tabular}

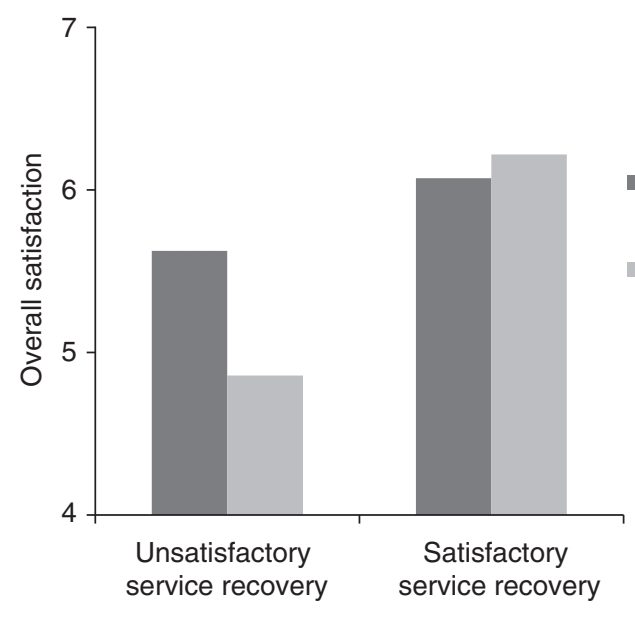

- Failure caused by customer

Failure caused by service provider

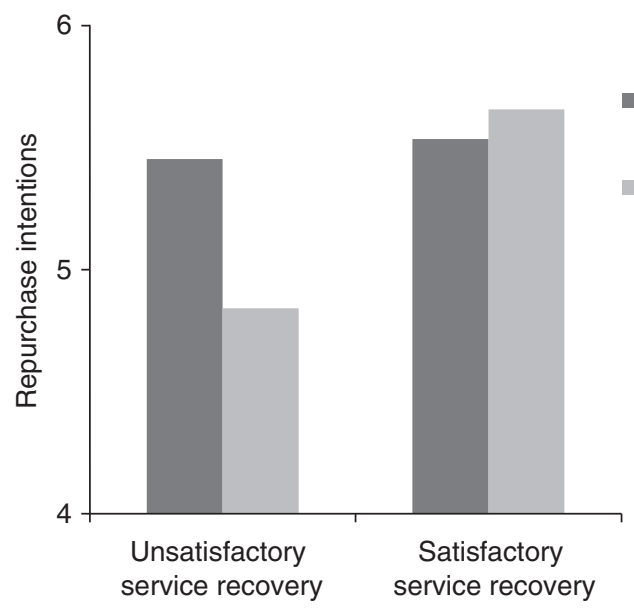

Figure 2. Interaction effects Study 2 
MSQ

23,6

506 reveal that if the hotel caused the failure, the means for overall satisfaction are 6.2 when observing a satisfactory recovery, and 4.9 when observing an unsatisfactory service recovery; when the complaining customer caused the failure, the means were 6.1 when observing a satisfactory recovery, and 5.6 when observing an unsatisfactory service recovery. These results suggest that the impact of observing an unsatisfactory service recovery on overall satisfaction is stronger if the hotel caused the failure than if the complaining customer caused the failure. This confirms $\mathrm{H} 3 \mathrm{a}$. If the hotel caused the failure, the means for repurchase intentions are 5.7 when observing a satisfactory recovery, and 4.8 when observing an unsatisfactory service recovery; if the complaining customer caused the failure, the means were 5.5 when observing a satisfactory recovery, and 5.5 when observing an unsatisfactory service recovery. Similar to the results for overall satisfaction, the impact of an observed service recovery is stronger if the customer caused the failure than if the service provider caused the failure. This confirms $H 3 b$. In addition to these findings, the results also show that if customers observe a satisfactory customer recovery, they maintain positive perceptions of the service provider, regardless of who caused the failure.

Discussion. The findings of Study 2 replicate and extend the findings of Study 1. Customers observing an unsatisfactory service recovery have lower overall satisfaction and repurchase intentions than customers observing a satisfactory service recovery, because the observation of a service recovery allows them to learn about the service provider's quality. However, the findings also indicate that service quality perceptions partially mediate the relationship between an observed recovery and overall satisfaction, and fully mediate the relationship between an observed recovery and repurchase intentions. This difference in effect might be explained by the nature of the dependent measures. Customer satisfaction is typically a backwardlooking measure, summarizing how well the service provider has been performing so far. In contrast, repurchase intentions is a forward-looking measure, describing how customers feel about using services from this service provider in the future (Gustafsson et al., 2005). Service quality fully explains why an observed service recovery leads to lower scores on the forward-looking metric in this study. This indicates that an observed recovery is an opportunity for customers to update their knowledge about the service quality of that service provider, after which they will decide whether or not they will use this service provider in the future. Regarding the backward-looking measure, service quality only partially explains why an observed service recovery impacts customer satisfaction. Therefore, examining other candidates for full mediation such as emotions (Porath et al., 2011) offers a fruitful avenue for future research.

\section{General discussion}

Across two studies, the findings demonstrate that whenever a service employee provides service recovery to a complaining customer, it impacts on the evaluations of customers observing this particular service recovery. Overall, this study contributes to the literature in three ways. First, the results indicate that observing an unsatisfactory recovery usually decreases the observing customers' outcomes, just as prior research shows that an unsatisfactory service recovery decreases the complaining customers' outcomes (e.g. Edvardsson et al., 2011; Van Vaerenbergh et al., 2012). However, the results suggest that a satisfactory service recovery has different impacts on complaining and observing customers. For observing customers, a satisfactory service recovery does not affect their evaluations of the service provider, when compared to the control condition in Study 1. For observing customers, a service recovery can hence 
be classified as a "dissatisfier," which is element that decreases customer outcomes when absent or badly performed, but does not increase customer outcomes when present or well performed (Johnston, 1995). In contrast, the receipt of a satisfactory service recovery may lead to higher levels of overall satisfaction and repurchase intentions in complaining customers (de Matos et al., 2007). For the complaining customer, a service recovery can be classified as a "critical" which is an element that decreases customer outcomes when absent or badly performed, and increases customer outcomes when present or well performed (Johnston, 1995). This first contribution is essentially the uncovering of the different impact of service recovery on complaining and observing customers.

Second, this study substantiates the potential for customers to learn through observation in the context of services. Previous research suggests that consumers can learn about product quality through observational learning (Zhang, 2010). However, the findings of this study indicates that this effect is also present in the service recovery context. As such, this paper responds to the call for research on learning effects in service encounters by Hibbert et al. (2012) and Libai et al. (2010). This paper also uncovers a potential explanation for lower customers evaluations of a service provider after observing an unsatisfactory service recovery. If a customer sees that a service provider treats another customer badly, this service recovery influences the observer's service quality perceptions; which in turn affect her/his evaluations of the service provider. Customers therefore do not rely on only their own experiences to gain insights about the service provider's service quality, they also rely on their observations of other customers' experience.

Third, this paper contributes by showing that observing an unsatisfactory service recovery does not lead inevitably to lower levels of customer satisfaction and repurchase intentions. Service providers can attenuate the negative consequences of an unsatisfactory service recovery by providing the observing customers with insights about who caused the failure. The link between observational learning theory and attribution theory received only limited attention in prior research (Kanfer et al., 1974). The findings of this study suggest that, in the context of observing a service recovery, these theoretical frameworks may be combined to explain observing customers' reactions to a recovery event. In contrast, if customers observe a satisfactory customer recovery, they do not take the cause of the failure into account when evaluating the service provider. This aligns with the "fix it, no matter what" principle that is advocated in literature (Lovelock and Wirtz, 2011). Hence, while service providers can benefit from explaining who caused the failure after the complaining customer has left, they should try to recover complaining customer, regardless of who caused the failure.

\section{Managerial implications}

From a managerial perspective, this research demonstrates the importance of providing a satisfactory service recovery to complaining customers, since an unsatisfactory service recovery would not only negatively impact on the complaining customer's outcomes but also on observing customers. This finding emphasizes the importance of installing appropriate service recovery procedures, to restore the complaining customer's satisfaction and behavioral intention, not only for the complaining customer him-/herself but also for the customers who are present. These service recovery tactics involve, for example, apologizing, showing empathy, giving an explanation, and providing compensation or restitution (Liao, 2007; Van Vaerenbergh et al., 2012). 
MSQ

23,6

508
Simply preventing other customers from observing the recovery is another way in which managers can avoid the negative consequences of observational learning. For example, service employees might handle complaints in a separate location, so that no other customers can observe whether the complaining customer received a satisfactory or unsatisfactory service recovery. Of course, some customers complain at the check-out instead of at the complaining desk. So check-out clerks should be trained to handle complaints as well. They can learn to ask the complaining customer for details about the service failure, and should receive training on how to solve customers' problems in an appropriate way. This can help them to determine who is responsible for this service failure and this information can be used by the service providers to explain who is responsible for the failure to the next customer. However, service providers must be cautious to prevent a culture of blame from emerging. When conducting research on this issue, researchers should stress the importance of being constructive when blaming others, and always focus on learning from errors (Fast, 2010). When indicating that the complaining customer caused the failure, the service provider should do so in a sincere manner, and avoid publicly humiliating the complaining customer. The service provider should also show that the organization is willing to learn from such failures. For example, in the second study, the complaining customer booked the room erroneously starting the fourth of next month, instead of the fourth of the current month. The service provider can, for example, explain to the next customer that he/she will pass the complaint on to the complaint department to see whether they can improve the online registration process. Such actions may even reinforce credibility (Davidow, 2003). These issues deserve attention in future research.

\section{Limitations and future research implications}

This study relies on scenario-based experiments; an approach with strong precedent in service recovery research. However, while scenarios enhance internal validity, their external validity might be limited. Consequently, future research should use more settings and different methodologies to replicate the findings of this study, and to extend the current findings. For example, adding a qualitative study using the critical incident technique may not only increase the external validity of the findings, but it may also provide more insights into an observed service recovery's effect on customer outcomes by uncovering personal and/or context-dependent characteristics that influence the effects. Another limitation is that we have only examined the effects of observing a recovery in the context of face-to-face service encounters. Given that customers also complain online (Andreassen and Streukens, 2013), researchers should examine whether observing a companies' online response to online complaints leads to similar responses.

Other dependent variables should also be examined in the future. For example, trust can also be examined as an outcome variable. Trust is a willingness to rely on a partner in whom one has confidence (Moorman et al., 1993), and observing a satisfactory service recovery may increase this confidence. Research should also examine whether observing a service recovery influences the observer's own complaint intention, if she/ he would experience a service failure. In a similar vein, research should also examine the situation in which the observing customer also planned to voice a complaint. Will the observation of an unsatisfactory response to another customer's complaint influence the observing customer's complaint intentions? Will the observation of a failed recovery make the next complainer more assertive, more likely to engage in verbal aggression, or change service recovery expectations? 
In this study, we examine locus of control attributions as a moderator. Subsequent research should examine other moderators of the relationship between an observed service recovery and customer outcomes. The current findings invite investigations of whether variables such as failure type, failure severity, or involvement moderate the relationships of an observed service recovery and customer outcomes.

Researchers should also assess whether and under which circumstances the observing customer is willing to help the complaining customer or the service employee. Research reveals that customers display customer citizenship behavior. This is defined as customers displaying voluntary and discretionary extra-role behavior, often with the aim of helping other customers (Groth, 2005). Explorations of the antecedents and consequences of an observing customer helping out a complaining customer or a service employee during service recovery appears to be worthwhile.

Finally, research indicates that customers learn about brands and services through word-of-mouth (Kuo et al., 2013; Wirtz et al., 2013). Researchers should compare the relative impacts of learning about service recovery through observation versus word-of-mouth on evaluations of a service provider.

In summary, although this study offers the first empirical investigation of the effects of observing a service recovery, more work in this area could further enhance our understanding of customers influence each other in service recovery encounters.

\section{References}

Anderson, N.H. (1971), "Integration theory and attitude change", Psychological Review, Vol. 78 No. 3, pp. 171-206.

Andreassen, T.W. and Streukens, S. (2013), "Online complaining: understanding the adoption process and the role of individual and situational characteristics", Managing Service Quality, Vol. 23 No. 1, pp. 4-24.

Bandura, A. (1971), Social Learning Theory, General Learning Press, New York, NY.

Bandura, A. (1977), Social Learning Theory, Prentice Hall, Englewood Cliffs, NJ.

Bikhchandani, S., Hirshleifer, D. and Welch, I. (1998), "Learning from the behavior of others: conformity, fads, and informational cascade", Journal of Economic Perspectives, Vol. 12 No. 3, pp. 151-170.

Bitner, M.J. (1990), "Evaluating service encounters: the effects of physical surroundings and employee responses", Journal of Marketing, Vol. 54 No. 2, pp. 69-82.

Cai, H., Chen, Y. and Fang, H. (2009), "Observational learning: evidence from a randomnized natural field experiment", American Economic Review, Vol. 99 No. 3, pp. 864-882.

Choi, B.J. and Kim, H.S. (2013), "The impact of outcome quality, interaction quality, and peer-to-peer quality on customer satisfaction with a hospital service", Managing Service Quality, Vol. 23 No. 3, pp. 188-204.

Cowley, E. (2005), "Views from consumers next in line: the fundamental attribution error in a service setting", Journal of the Academy of Marketing Science, Vol. 33 No. 2, pp. 139-152.

Cronin, J. Jr, Brady, M.K. and Hult, T.M.G. (2000), "Assessing the effects of quality, value, and customer satisfaction on consumer behavior intentions in service environments", Journal of Retailing, Vol. 76 No. 2, pp. 193-218.

Davidow, M. (2003), "Organizational responses to customer complaints: what works and what doesn't”, Journal of Service Research, Vol. 5 No. 3, pp. 225-250.

de Matos, C.A., Henrique, J.L. and Rossi, C.A.V. (2007), "Service recovery paradox: a metaanalysis", Journal of Service Research, Vol. 10 No. 1, pp. 60-77. 
MSQ

23,6

510

De Ruyter, K., Wetzels, M. and Bloemer, J. (1998), "On the relationship between perceived service quality, service loyalty, and switching costs", International Journal of Service Industry Management, Vol. 9 No. 5, pp. 436-453.

Edvardsson, B., Tronvoll, B. and Höykinpuro, R. (2011), "Complex service recovery processes: how to avoid triple deviation", Managing Service Quality, Vol. 21 No. 4, pp. 331-349.

Fast, N. (2010), "How to stop the blame game", available at the Harvard Business Review blog: http://blogs.hbr.org/research/2010/05/how-to-stop-the-blame-game.html (accessed May 13, 2013).

Gawronski, B., Rydell, R.J., Vervliet, B. and De Houwer, J. (2010), "Generalization versus contextualization in automatic evaluation", Journal of Experimental Psychology: General, Vol. 139 No. 4, pp. 683-701.

Goodman, J. (1999), "Basic facts on customer complaint behavior and the impact of service on the bottom line", Competitive Advantage, June, pp. 1-5.

Goodwin, C. and Spiggle, S. (1989), “Consumer complaining: attributions and identities", Advances in Consumer Research, Vol. 16, pp. 17-22.

Grewal, D., Roggeveen, A.L. and Tsiros, M. (2008), "The effect of compensation on repurchase intentions in service recovery", Journal of Retailing, Vol. 84 No. 4, pp. 424-434.

Grönroos, C. (1988), "Service quality: the six criteria of good perceived service quality", Review of Business, Vol. 9 No. 3, pp. 10-13.

Groth, M. (2005), "Customers as good soldiers: examining citizenship behaviors in internet service deliveries", Journal of Management, Vol. 31 No. 1, pp. 7-27.

Gruber, T., Szmigin, I. and Voss, R. (2009), "Handling customer complaints effectively: a comparison of the value maps of female and male complainants", Managing Service Quality, Vol. 19 No. 6, pp. 636-656.

Gustafsson, A., Johnson, M.D. and Roos, I. (2005), "The effects of customer satisfaction, relationship commitment dimensions, and triggers on customer retention", Journal of Marketing, Vol. 69 No. 4, pp. 210-218.

Hair, J.F., Black, B., Babin, B., Anderson, R.E. and Tatham, R.L. (2006), Multivariate Data Analysis, 6th ed., Pearson-Prentice Hall, Upper Saddle River, NJ.

Hibbert, S., Winklhofer, H. and Temerak, M.S. (2012), "Customers as resource integrators: toward a model of customer learning”, Journal of Service Research, Vol. 15 No. 3, pp. 247-261.

Johnston, R. (1995), "The determinants of service quality: satisfiers versus dissatisfiers", International Journal of Service Industry Management, Vol. 6 No. 5, pp. 53-71.

Kanekar, S. (1976), "Observational learning of attitudes: a behavioral analysis", European Journal of Social Psychology, Vol. 6 No. 1, pp. 1-24.

Kanfer, F.H., Karoly, P. and Newman, A. (1974), "Source of feedback, observational learning, and attitude change", Journal of Personality and Social Psychology, Vol. 29 No. 1, pp. 30-38.

Kowalski, R.M. (2003), Complaining, Teasing, and Other Annoying Behaviors, Yale University Press, New Haven, CT.

Kuo, Y.-F., Hu, T.-L. and Yang, S.-C. (2013), "Effects of inertia and satisfaction in female online shoppers on repeat-purchase intention: the moderating roles of word-of-mouth and alternative attraction”, Managing Service Quality, Vol. 23 No. 3, pp. 168-187.

Larivière, B. (2008), "Linking perceptual and behavioral customer metrics to multiperiod customer profitability: a comprehensive service-profit chain application", Journal of Service Research, Vol. 11 No. 1, pp. 3-21.

Liao, H. (2007), "Doing it right this time: the role of employee service recovery performance in customer-perceived justice and customer loyalty after service failures", Journal of Applied Psychology, Vol. 92 No. 2, pp. 475-489. 
Libai, B., Bolton, R.N., Bügel, M.S., de Ruyter, K., Götz, O., Risselada, H. and Stephen, A.T. (2010), "Customer-to-customer interactions: broadening the scope of word of mouth research", Journal of Service Research, Vol. 13 No. 3, pp. 267-282.

Lii, Y.-S. and Lee, M. (2012), "The joint effects of compensation frames and price levels on service recovery of online pricing error", Managing Service Quality, Vol. 22 No. 1, pp. 4-20.

Lin, H.-H., Wang, Y.-S. and Chang, L.-K. (2011), "Consumer responses to online retailer's service recovery after a service failure: a perspective of justice theory”, Managing Service Quality, Vol. 21 No. 5, pp. 511-534.

Lovelock, C.H. and Wirtz, J. (2011), Services Marketing: People, Technology, Strategy, 7th ed., Pearson-Prentice Hall, Upper Saddle River, NJ.

Masia, C.L. and Chase, P.N. (1997), "Vicarious learning revisited: a contemporary behavior analytic interpretation", Journal of Behavioral Therapy and Experimental Psychiatry, Vol. 28 No. 1, pp. 41-51.

Maxham, J.G. III and Netemeyer, R.G (2002), “A longitudinal study of complaining customers' evaluations of multiple service failures and recovery efforts", Journal of Marketing, Vol. 66 No. 4, pp. 57-71.

Michel, S., Bowen, D.E. and Johnston, R. (2009), "Why service recovery fails: tensions among the customer, employee and process perspectives", Journal of Service Management, Vol. 20 No. 3, pp. 253-273.

Miller, J.L., Craighead, C.W. and Karwan, K.R. (2000), "Service recovery: a framework and empirical investigation”, Journal of Operations Management, Vol. 19 No. 4, pp. 387-400.

Moorman, C., Deshpande, R. and Zaltman, G. (1993), "Factors affecting trust in market relationships", Journal of Marketing, Vol. 57 No. 1, pp. 81-101.

Orsingher, C., Valentini, S. and de Angelis, M. (2010), "A meta-analysis of satisfaction with complaint handling in services", Journal of the Academy of Marketing Science, Vol. 38 No. 2, pp. 169-186.

Ozgen, O. and Kurt, S.D. (2012), "Pre-recovery and post-recovery emotions in the service context: a preliminary study”, Managing Service Quality, Vol. 22 No. 6, pp. 592-605.

Peterson, R.A. (2001), "On the use of college students in social science research: insights from a second-order meta-analysis", Journal of Consumer Research, Vol. 28 No. 3, pp. 450-461.

Porath, C.L., MacInnis, D. and Folkes, V.F. (2011), "It's unfair: why customers who merely observe an uncivil employee abandon the company", Journal of Service Research, Vol. 14 No. 3, pp. 302-317.

Preacher, K.J. and Hayes, A.F. (2004), "SPSS and SAS procedures for estimating indirect effects in simple mediation models", Behavior Research Methods, Instruments, and Computers, Vol. 36 No. 4, pp. 717-731.

Priluck, R. and Lala, V. (2009), "The impact of the recovery paradox on retailer-customer relationships”, Managing Service Quality, Vol. 19 No. 1, pp. 42-59.

Russell, D. (1982), "The causal dimension scale: a measure of how individuals perceive causes", Journal of Personality and Social Psychology, Vol. 42 No. 6, pp. 1137-1145.

Smith, A.K., Bolton, R.N. and Wagner, J. (1999), "A model of customer satisfaction with service encounters involving failure and recovery", Journal of Marketing Research, Vol. 36 No. 3, pp. 356-372.

Svari, S., Svensson, G., Slatten, T. and Edvardsson, B. (2010), "A DIP-construct of perceived justice in negative service encounters and complaint handling in the Norwegian tourism industry", Managing Service Quality, Vol. 20 No. 1, pp. 26-45.

Van Vaerenbergh, Y., Larivière, B. and Vermeir, I. (2012), "The impact of process recovery communication on customer satisfaction, repurchase intentions, and word-of-mouth intentions", Journal of Service Research, Vol. 15 No. 3, pp. 262-279. 
MSQ

23,6

512
Weiner, B. (2000), "Attributional thoughts about consumer behavior", Journal of Consumer Research, Vol. 27 No. 3, pp. 382-387.

Wirtz, J., Orsingher, C., Chew, P. and Kuan Tambyah, S. (2013), "The role of metaperception on the effectiveness of referral reward programs", Journal of Service Research, Vol. 16 No. 1, pp. 82-98.

Zhang, J. (2010), "The sound of silence-evidence of observational learning from the U.S. kidney market”, Marketing Science, Vol. 29 No. 2, pp. 315-335.

Zhao, X., Lynch, J.G. Jr and Chen, Q. (2010), "Reconsidering Baron and Kenny: Myths and truths about mediation analysis", Journal of Consumer Research, Vol. 37 No. 2, pp. 197-206.

\section{Further reading}

Weiner, B. (1985), "An attributional theory of achievement motivation and emotion", Psychological Review, Vol. 92 No. 4, pp. 548-573.

\section{About the authors}

Dr Yves Van Vaerenbergh is an Assistant Professor of Marketing at Hogeschool-Universiteit Brussel, where he is a Member of the Human Relations Research Group. He is also affiliated to the Center for Service Intelligence, Ghent University. His research focusses on dissatisfying experiences in service encounters, such as service failures, service recovery, or being served in a second language. He has published in Journal of Service Research, Service Industries Journal, European Journal of Marketing, and International Journal of Public Opinion Research. Dr Yves Van Vaerenbergh is the corresponding author and can be contacted at: yves.vanvaerenbergh@ kuleuven.be

Iris Vermeir is a Professor of Marketing at Ghent University and University College Ghent, and is a Member of the Center for Service Intelligence, Ghent University. Her research interests include consumer choice behavior, consumer ethics, and sustainable consumer behavior. She has published in several international journals like Journal of Consumer Research, Journal of Service Research, Journal of Business Research, Journal of Business Ethics, and Ecological Economics. She is the recipient of several research grants awarded by the Research Foundation Flanders and University College Ghent Research Fund.

Bart Larivière is an Assistant Professor of Service Management at Ghent University, where he is a Founder and Executive Director of the Center for Service Intelligence. His research focusses on customer loyalty, service recovery, and multichannel management, and has been published in Journal of Service Research, Journal of Service Management, Journal of Interactive Marketing, the European Journal of Operational Research, and Expert Systems with Applications. He is an ad hoc Reviewer for Journal of Service Research and Journal of Marketing. He was a finalist for best paper in Journal of Service Research and won the Best Practitioner Presentation Award (twice) at the Frontiers in Service Conference.

To purchase reprints of this article please e-mail: reprints@emeraldinsight.com Or visit our web site for further details: www.emeraldinsight.com/reprints 